\title{
Getting information to disadvantaged rural communities: the centre approach
}

\author{
Maritha Snyman and Retha (MMM) Snyman \\ Department of Information Science, University of Pretoria, South Africa \\ mesnyman@postino.up.ac.za\&msnyman@postino.up.ac.za
}

Received:29 $9^{\text {th }}$ November 2002

Revised: $25^{\text {th }}$ February 2003

The South African Constitution entrenches the right of every citizen to receive or impart information or ideas. Information and communications technology (ICT) can play an important role in facilitating the upgrading of education, health care, recreation and other services, by improving the quality of information available and by providing communities throughout the country with access to expertise and usable information. One of the objectives of the article is to indicate how the government envisaged and implemented its resolve to improve the communications technology infrastructure for the dissemination of usable information to rural disadvantaged communities by focusing on the centre approach. A second objective is to report on the present status - successes and failures - of the most important of these initiatives.

Keywords: Citizen's Community Centres; Information and Communications Technology; Multi-Purpose Community Centres; Telecentres

\section{Introduction}

The South African Constitution entrenches the right of every citizen to receive or impart information or ideas (South Africa 1996). Telecommunications and an information infrastructure (ANC 1994: 2.8.1) are mentioned in the ANC's election manifesto, the Reconstruction and Development Programme (RDP), as the intended measures to operationalise this right. The intent was to improve the quality of information available and providing communities throughout the country with access to expertise and usable data (ANC 1994: 4.6.6. -.8).

South African leaders have, since the early days of the ANC government, been convinced that information and communications technologies (ICT) should be used to disseminate information to disadvantaged South African communities, and that this would become a positive force for social change. Naidoo (1998), a former minister for Posts, Telecommunications and Broadcasting, stated, for example, that '.. there is a direct, positive correlation between access to telecommunications and socio-economic development ... telecommunications is no longer the consequence of development, rather it is a necessary precondition'. The South African government supports the notion that there is a direct and positive correlation between access to telecommunications and socio-economic development in the Global Information Society and that ICT can play a catalysing role in the functioning of the economic and social sectors (Van Audenhove 1999).

Over the past few years several initiatives in the area of infrastructure development and applications have indicated that government seriously intends to improve telecommunications services for a larger section of the population. In the restructuring of the telecommunications sector, the government has also attempted to address the needs of the poor who predominantly live in rural areas'. South African government officials have often accentuated the important role that the provision of ICT could play in accelerating development in rural areas. Mbeki (1995:2I), for instance, states that 'the modern communications technology ... must help us educate our children, particularly in the rural and other underdeveloped areas of our country', while Naidoo (1997:I) stresses that the government is committed 'to bring electronic health care to remote rural clinics, Internet to schools, and distance learning to those in the hinterland of the country ... (for) creating a better life'.

Against this background this study aims:

- to indicate how the government envisaged and implemented its resolve to improve communications technology infrastructure for the dissemination of usable information to rural disadvantaged communities by focusing on the centre approach; and

- to investigate the present status - successes and failures - of the most important of these initiatives.

I. Of the $76,7 \%$ (31,3 million) previously disadvantaged Blacks, only 13,6 million are living in urban areas and I7,8 million (57\%) are living in non-urban areas (Survey of the IT industry and related jobs and skills in South Africa, 1999:2I). 


\section{Initiatives of the South African government}

Since 1996 the initiatives launched by government to implement its resolve to improve the ICT infrastructure for the provision of information to the country's peoples have included the following:

I. The promulgation of the Telecommunications Act no. 103 of 1996 (South Africa 1996). The post-apartheid government was left with a modern telecommunications infrastructure but one that was highly skewed in favour of white and urban areas. Shortly after the elections in 1994, Pallo Jordan, the then Minister of Posts, Broadcasting and Telecommunications, started a consultative process for the restructuring of the telecommunications sector (Van Audenhove 1999:12). In 1996 the Telecommunications Act was promulgated to provide for, among other matters, the Universal Service Agency (USA) responsible for ensuring universal access to all telecommunications services (South Africa 1996).

2. Shortly after the promulgation of the Act the government sold a $30 \%$ stake in Telkom to a consortium comprised of SBC International and Telecom Malaysia to attract partners with the necessary capital, technology, and expertise (South Africa Yearbook 2000: 489).

3. In May 1997 Telkom was given a licence which stipulated that Telkom had to provide a total of 2,8I million new access lines in 5 years, of which 1,67 million were to be reserved for under-serviced areas (South Africa 1997).

4. The Department of Communications launched Info.com 2025 to establish a networked information community. The objectives included inter alia:

- universal access to telephone services by all communities and particularly through telecentres and Public Information Terminals (PiTs);

- data-quality connections for all users desiring access to the Internet and other data-related network services available to the public;

- full integration of communication and information technology in the health care sector through tele-medicine, and

- Internet 2000 with the objective of offering access to the Internet to a defined percentage of schools by the year 2000 (South Africa. Department of Communications 1998).

5. A Task Group on Government Communications (ComTask) was appointed in December 1995 to investigate and make recommendations about government communications and its structures, media ownership and control and the relationship between government and the civil society. In line with the ComTask recommendations, the government established the Government Communication and Information Services (GCIS) to replace the South African Communication Services (SACS). The GCIS had to focus on the following priority areas:

- coherent government communications;

- development information;

- effective use of information technology;

- relations with the media, media diversity, and training and industry-wide relations (Strydom 1998), and

- the establishment of Multi-Purpose Community Centres (MPCCs) to disseminate useful information about government and other matters to the South African public (ComTask 1996).

It is clear that the government included in its initiatives Telecentres, MPCCs and other community ICT centres as ways of empowering communities to be part of the information society.

\section{Getting telecommunications and information to disadvantaged rural areas: the centre approach}

Faced with problems such as poverty, poor infrastructure with regard to electricity and telephone lines as well as low education levels and computer skills, the South African government decided on the centre approach as a viable option to place ICTs and other information services within reach of disadvantaged rural South African communities.

The 'centre approach' refers to the practice of establishing centres as information resources and communications nodes (Benjamin et al. 2000) in disadvantaged rural areas to meet the telecommunications and information needs of the members of such communities. This approach is widely acclaimed as a solution to bridge the digital divide.

The government's inclination towards the centre approach was mentioned for the first time in a paper delivered at the Information Society and Development (ISAD) Conference in 1996 where one of the main proposals was the possibility of establishing MPCCs to provide community access (NITF 1996). Berlyn (1998) also mentions the use of MPCCs, telecentres and other community IT centres as possible ways of empowering communities in the Information Society. In 1997, Chapter 5 of the ComTask report (ComTask 1996) was devoted to improving community access to information, particularly through MPCCs and community IT centres. About the same time the International Development Research Centre (IDRC) commissioned the National IT Forum (NITF) to investigate the possibility of establishing MPCCs in South Africa. This led to the publication in 1998 of a study on the use of IT in community projects, showing many hundreds of existing centres (Benjamin 1998). In the first quarter of 1999 the GCIS commissioned a study on community information needs. A report called A framework for Memorandum on Government Information Centres (South Africa. GCIS, 
1999a) was accepted by the provincial communications partners, and later the same year led to a conclusion that MPCCs were a viable channel and institutional structure for development information and the implementation of the government's communications strategy of July 1999: A nation at work for a better future (South Africa. GCIS 1999b).

It was envisaged that MPCCs should form the backbone of development communications and the dissemination of information. They should offer a wide range of services tailored to the specific needs of communities and should play a major role in 'educating the various communities and disseminate information to both rural and urban communities' (Berlyn 1998). The key input that the GCIS hoped to make was to identify community information needs and provide as much of that information as possible (Pahad 1998). 'At the same time, the strategic nature of these centres as means through which citizens can communicate with government (were to) be promoted' (Pahad 1998).

An MPCC can be defined as an integrated community development centre (Berlyn 1998). Ideally, community participation should form the basis of such a centre that is to address people's information needs by providing relevant services. MPCCs aim to empower the poorest and most disadvantaged communities with access to government and nongovernment information and services. They are described as 'one-stop shops' through which communities can access government services, information technology and training (Safrica 2002).

Although not explicitly stated in the Telecommunications Act of 1996 (South Africa 1996), the USA was made responsible for furthering the goal of universal access and universal service by erecting telecentres. The idea behind telecentres was twofold: to extend services to under-serviced areas by a type of community service, and to provide additional business-related services such as fax, Internet and photocopying. These services were to support the policy of tele-governance and distance education. The initial target of the USA was to build about 100 telecentres a year (Van Audenhove 1999).

The Department of Communications also produced several documents outlining various other projects for extending access to ICTs. Public Information Terminals (PiTs) were to be placed in post offices and Internet labs in previously disadvantaged areas (South Africa. Department of Communications 1998). The objective of PiTs was 'to create a communication infrastructure through which the public will have access to information from Government/business as well as be empowered to communicate via Internet or e-mail with the party of their choice' (South African Post Office 1999:1).

In 2000 a status report on MPCCs mentioned that in January 2000 'an amount of R2 million was transferred to the USA ... to extend digital communications infrastructure and its benefits to ... rural communities' (Maphatane 2000:I). Internet labs were later incorporated in what would become known as Citizen's Post Offices. They would offer the following services at selected outlets in deep rural areas:

- Internet and e-mail facilities (accessed by way of pre-paid cards)

- Telephone and faxing facilities (incoming and outgoing)

- Document compilation.

'Citizen's Post Offices are essentially "Internet cafes" for disadvantaged areas (Your office in the Post Office)' (Post Office 200I: 4).

\section{Why choose the centre approach?}

The South African government's decision to choose the centre approach was probably supported and motivated by a global trend.

In the beginning of the 1980s the idea that computers connected to the telecommunication network could be used for community purposes originated in developed Western countries. The first tele-café opened in Santa Monica, Los Angeles (Schuler 1996) and more or less at the same time the first multifunctional telecentres opened in a Danish library and in a grocery shop in Sweden (Gaspar 2002), while the first Hungarian community-purpose computer room opened in a restaurant in Dunskeszi (Gaspar 2002). The establishment of these centres was prompted by the isolation of rural communities from the information highway and consequently the new economy.

The idea at first spread through Western Europe and then to the rest of the world including the developing countries. Since the 1990s, the United Nations (UN) body responsible for telecommunications, the International Telecomms Union (ITU) has been establishing and supporting telecentre projects in developing countries, and since the mid-1990s many other international donors have joined this trend (Benjamin 2000).

In the developing countries these centres were quickly linked to economic and social development efforts at community level. The 1998 World Bank report described a telecentre as 'a powerful engine of rural development and a preferred instrument in the fight against poverty' (World Bank 1998). The ITU World Telecommunications Development Report of 1998 (ITU 1998) stated that telecentres could play an important role in national strategies for universal access in view of the fact that full universal service (a phone in every home) is not a realistic goal for developing countries.

SA JnI Libs \& Info Sci 2003, 69(2) 
The optimistic perception that access to ICTs would solve many social and developmental problems was one of the reasons the centre approach was heralded as the solution to the ever-widening digital divide. It is advocated that the development of disadvantaged communities in the South could be accelerated by the provision of ICT access in ICTbased community centres. Ernberg (1998) describes, for instance, how rural community centres can empower communities in the information society and argues how access to such technologies could be vital to the economic development of disadvantaged communities. African and Asian case studies to prove these points are described by, amongst others, Richardson \& Paisley (1998), Richardson, (1997) and Kiplang'at (1999).

\section{Defining the centre approach}

The centre approach is characterised throughout the world by diversification and variety. A generic name that expresses all the different variations of what is currently associated with the centre approach has not yet been found. Colle and Roman (1999) have counted over 30 different names for these kinds of centres, including telecottages, multipurpose community centres, community technology centres, community communication centres, info shops, community access centres, and others. The term 'telecentre' is preferred in current discourses on this issue (Gaspar 2002) and will be used as generic term in this paper when referring to ICT centres based in communities.

Conradie (1998), as well as most other sources, refers to the existence of different categories of telecentres. The report of the National Telecomms Cooperative Association (NTCA 1999) of the United States of America distinguishes, for instance, three categories of telecentres, namely basic telecentres, multi-purpose community telecentres (MPCTs) and phone shops.

The only comprehensive South African study, the DRA-Development and LINK Centre report of Benjamin et al. (2000) identifies three similar broad categories of telecentres in South Africa, namely phone shops, telecentres and MPCCs. The IDRC's Telecentre case study in South Africa (Espitia 200I) makes a distinction between multipurpose telecentres, community multipurpose telecentres, mini-telecentres and standard telecentres. The last category refers, amongst others, to telecentres of the Universal Service Agency (USA). This report also includes community radio, computer training centres, schools and libraries in their categorisation of telecentres.

Since, for the purposes of this article, only government initiatives are being reviewed, phone shops such as the Vodacom and Telkom shops will not be evaluated. In South Africa, they are in general private profit-seeking enterprises, situated mainly in urban areas, with no developmental intentions and with a focus on the provision of telecommunications (Benjamin et al. 2000:6; Snyman et al. 200I).

Telecentres and MPCCs are, however, nearly always subsidised and supported in various ways by government or donors and require extensive external support. Only the MPCCs established by government and telecentres of the USA will be discussed.

PiTs and Citizen's Post Offices (CPOs) were not discussed in the DRA-development and LINK Centre report (Benjamin et al. 2000). Due to the fact that PiTs are stand-alone units that can be (and were later) placed in any location and are not, due to the skewed distribution of post offices in South Africa, available in most instances to the needy rural populations, they will be left out of the evaluation to follow. CPOs, operating in rural post offices as Internet labs, comply with the synthesised definition of telecentres provided in Table I and will therefore be included in the discussion.

Telecentres of the USA, MPCCs and CPOs can, in summary, be regarded as the most important vehicles for the centre approach chosen by government to 'offer(ing) a range of developmental services (including information services) ... to the people out there' (Berlyn 1998:21). The present status of these initiatives will be discussed below.

\section{The present status of the government's initiatives with regard to telecentres}

Although the above-mentioned initiatives of government are, without doubt, commendable and follow international trends, it is opportune to reflect on the viability of the centre approach in the South African context, especially since Benjamin et al. (2000: 6) have concluded in their report that few of the government's initiatives that they had investigated were successful.

In assessing the current status of the government's centre initiatives with regard to rural community ICT centres, previous studies and information provided by government itself e.g. on web sites and in personal communication with government officials will be combined with empirical research conducted for the purposes of this paper.

The empirical research component consists of telephone interviews at selected sites. Telephonic interviews were conducted with relevant spokespersons at existing USA telecentres, CPOs and MPCCs between June and August 2002. All the USA telecentres, CPOs and MPCCs that appeared on lists provided by the GCIS, the South African Post Office

and the USA respectively were contacted telephonically during office hours. If after three attempts a specific centre could 
not be reached, it was assumed that the centre was not effective or not operating in line with general expectations or closed down.

\section{USA telecentres}

The initial target of the USA was to erect about 100 telecentres a year starting in 1998. An estimated 3000 to 4000 are needed for full coverage of the country (Van Audenhove 1999). In 1998 the USA openly admitted several problems with the first telecentres (Khumalo 1998). These included the lack of financial systems at the telecentres, inadequate training of the managers, no clear tariff structure, unclear expectations (several managers expected salaries from the USA) as well as theft without property being insured. The report concluded that the telecentre organisations were not in a position to properly manage their business. They were unclear about their responsibilities. The USA did not have a management system to monitor the performance of the telecentres or detect misuse and misappropriations, should they occur. The need to clarify the role of the USA as franchiser was also mentioned. The report recommended that it would not be good acceptable practice to go ahead with the implementation on a large scale before proper management could be guaranteed (Khumalo 1998).

Schreiner (1999) confirmed that there were serious problems with regard to the USA's telecentres. She found that the great enthusiasm around the launch of the first telecentre in April 1998 was not fulfilled. There were frequent technical problems and little support from the USA for the managers.

The DRA-Development and LINK Centre report (Benjamin et al. 2000) found only 65 USA telecentres in operation, of which only five were online. Only 40 of the remaining 60 telecentres had working telephone lines. A geographical breakdown of the 65 USA telecentres does, however, indicate that most of the USA telecentres are situated in the Northern Province, Eastern Cape and KwaZulu-Natal, areas where most of South Africa's poor, unemployed and previously disadvantaged people live (Snyman et al. 200I).

The website of the USA was down and under construction during June and July 2002 when the research was conducted. The Community web site (http://www.communitysa.org.za) that contains the most comprehensive listing of telecentres in South Africa, was then consulted. This list does not, however, indicate which of the telecentres have been established by the USA, and was last updated on 24 May 2000.

After many fruitless attempts to get information from officials of the USA, a representative of the USA eventually provided a 'Telecentre information list' on 18 June 2002 containing information about the existing USA telecentres. The list obtained from the USA provided information about the type of ownership of the telecentres, their geographical locations, contact numbers and contact persons as well as a categorisation of telecentres which refers to telecentres at MPCC sites, pilot telecentres, telecentres at IDRC sites, telecentres at KPN sites, women's telecentres, relocated telecentres and multipurpose telecentre sites.

During June and July 2002 each of the telecentres on the list was contacted by telephone and a telephonic interview conducted with the manager and/or assistant available. The objectives of the interviews were to establish which services are offered and used and what the general usage profile (number of visits per day, services used and the perceived needs of the users) consist of.

Trying to make telephonic contact with the telecentres proved to be no easy task. Of the 56 telecentres only 25 could be reached telephonically (44,6\%). At 16 of the telecentres nobody answered the phone (28,6\%); eight more telecentres either have no telephones; or the number provided was incorrect, or the telephone was out of order or did not exist (14,3\%). Seven of the 56 telecentres (12.5\%) had, as far as could be established, closed down. This means that less than $50 \%$ of the telecentres could be reached by telephone during office hours. The interviews were therefore only conducted with 25 out of a possible 56 telecentres listed by the USA.

Telecommunications services such as public phones are available at 17 telecentres, fax facilities at 18 and Internet connection at 9 telecentres. If problems with telephone lines can be sorted out, telecommunications services could be extended to 8 more telecentres. Services such as photocopying, word processing and computer training predominate these three services are not dependent on a telecommunications infrastructure.

Only at a few telecentres are there signs of an entrepreneurial spirit that should be the key to increasing the limited rural self-employment rate. One telecentre is used for church services, one provides postal facilities, one sells telephone cards, one newspapers and one refreshments and condoms.

The data, collected by means of the telephonic interviews, is presented in the table below. 
Table I Profile of USA telecentres in June/July 2002

\begin{tabular}{|c|c|c|c|c|c|}
\hline & Telecentre & Town and province & Services offered & Services mostly used & $\begin{array}{l}\text { Clients } \\
\text { per day }\end{array}$ \\
\hline 1 & Acornhoek & Acornhoek/Limpopo & $\begin{array}{l}\text { PP, PSC, fax, Cp } \\
\text { refreshments, } \\
\text { condoms }\end{array}$ & $P P, f a x, C p$ & 70 \\
\hline 2 & Alice & Middledrift/EC & \multicolumn{3}{|c|}{ Phone engaged. Out of order? } \\
\hline \multirow[t]{2}{*}{3} & \multirow{2}{*}{$\begin{array}{l}\text { Apel } \\
\text { I }\end{array}$} & \multirow[t]{2}{*}{ Apel/NW } & Fax, Cp, tel, WP & Copy, fax, WP & $20-30$ \\
\hline & & & \multicolumn{3}{|c|}{ Problems with Telkom lines past 4 years. } \\
\hline 4 & Bakenberg & Pietersburg/Limpopo & \multicolumn{3}{|c|}{$\begin{array}{l}\text { The telephone number on the list is the number of the Provincial } \\
\text { Revenue Office. They know nothing about a telecentre. }\end{array}$} \\
\hline 5 & Bakgaga ba Mothapo & Pietersburg/Limpopo & \multicolumn{3}{|l|}{ No answer. } \\
\hline 6 & Batlokwa Women Forum & Dwarsrivier/Limpopo & $\begin{array}{l}P P, C p, f a x, C T, W P \\
\text { sells newspapers }\end{array}$ & WP. Cp & 200 \\
\hline 7 & Bekuzulu & Vryheid/KZN & \multicolumn{3}{|l|}{ No answer. } \\
\hline 8 & Bhamshele & Kwa-Maphumulo/KZN & $\begin{array}{l}C T, W P, P P \\
C p\end{array}$ & PPs & 300 \\
\hline 9 & Boitekong & Rustenburg/NW & WP, Cp & WP, Cp & 20 \\
\hline 10 & Clocolan & Clocolan/FS & \multicolumn{3}{|l|}{ No answer. } \\
\hline II & Driefontein-Mgazini & Ladysmith/KZN & \multicolumn{3}{|c|}{ The telecentre is closed. It operated for only three months. } \\
\hline 12 & Ekuphumuleni & Eshowe/KZN & PP, Cp, CT, fax & WP & 50 \\
\hline 13 & Embekweni/Kanya & Paarl/WC & \multicolumn{3}{|c|}{ Number constantly busy. Out of order? } \\
\hline 14 & Emma Rikhotso & Winterveldt/NW & \multicolumn{3}{|l|}{ No answer } \\
\hline 15 & Etafuleni & Inanda & Cp, CT, PP, IN, & PP, Cp, advice, church & 200 \\
\hline 16 & Ex-combatant Ass & Vryburg/WC & \multicolumn{3}{|c|}{$\begin{array}{l}\text { There is no telephone at the centre. Was also unable to reach } \\
\text { the Lesedi Community Advice centre next door. }\end{array}$} \\
\hline 17 & Flagstaff & Flagstaff/EC & \multicolumn{3}{|c|}{ Phone goes directly to voicemail. } \\
\hline 18 & Gasaleka & Gasaleka/Limpopo & $\begin{array}{l}P P, C p, \text { fax, WP, CT, } \\
\text { IN, Post Office }\end{array}$ & Post, PP, CT, WP & 100 \\
\hline 19 & Ikhwezi & Brakpan/Gauteng & WP, fax, IN & WP & 20 \\
\hline 20 & Ipelegeng & SchweizerReinecke/NW & PP, IN, Cp, fax & Cp, PP, WP & $50-100$ \\
\hline 21 & Jan Kemp & Jan Kempdorp/NC & \multicolumn{3}{|l|}{ No answer. } \\
\hline 22 & Khayelitsha & Khayelitsha/WC & \multicolumn{3}{|l|}{ Wrong number. } \\
\hline 23 & Lebotloane/Lerechabetse & Hammanskraal/NW & \multicolumn{3}{|c|}{ Phones switch over to voice mail. } \\
\hline 24 & Leliefontein & Leliefontein/WC & \multicolumn{3}{|c|}{ Telecentre closed due to sponsors not paying accounts. } \\
\hline 25 & Lwamondo Vuwani & Thoyando/Limpopo & \multicolumn{3}{|l|}{ Wrong number } \\
\hline 26 & Machibini/Lady Frere & Queenstown/EC & Cp, PP, fax, WP & PP & $15-20$ \\
\hline 27 & Mafahlaneng/Tweeling & Tweeling/FS & $\mathrm{PP}, \mathrm{CP}, \mathrm{CT}$ & $\mathrm{PP}$ & 50 \\
\hline \multirow[t]{2}{*}{28} & \multirow[t]{2}{*}{ Makoko } & \multirow[t]{2}{*}{ WhiteRiver/Mpumalanga } & Cp, WP, fax, PP & WP, PP & 4 \\
\hline & & & \multicolumn{3}{|c|}{ Phone lines not working. Clients are frustrated. } \\
\hline 29 & Mangaung & Bloemfontein/FS & $\begin{array}{l}\text { PP, fax, } \\
\text { Cp, IN, WP }\end{array}$ & PP, IN (students) & $40-50$ \\
\hline 30 & Mankweng & Pietersburg/Limpopo & Cp, WP, Fax, CT & $\mathrm{CT}$ & 30 \\
\hline \multirow[t]{2}{*}{31} & \multirow[t]{2}{*}{ Marquard } & Marquard/FS & PP, PSC, IN, WP, Fax & $C_{p}, \mathrm{PP}, W P$ & $42-50$ \\
\hline & & & Fax and PP only availab & when telephone lines are & rking. \\
\hline 32 & Masana & Rustenburg/NM & No answer. & & \\
\hline 33 & Matatiele & Matatiele/EC & No answer. & & \\
\hline 34 & Modimosana & Rustenburg/NW & No answer. & & \\
\hline 35 & Mpukunyoni & Mtubatuba/KZN & Not open at present. $\mathrm{H}$ & pe to reopen. & \\
\hline 36 & Ndevana & Ndevana/EC & PP, fax, Cp, IN & PP, fax, IN & 100 \\
\hline 37 & Ndumo & Qotho/KZN & CT, Cp, fax, WP & CT, Cp, WP & 50 \\
\hline & & & Telkom services were & opped due to high costs. & \\
\hline
\end{tabular}




\begin{tabular}{|c|c|c|c|c|c|}
\hline 38 & Ndundulu & Nkwalini & \multicolumn{3}{|c|}{$\begin{array}{l}\text { The phone was repeatedly answered by people who said that } \\
\text { they knew nothing about a telecentre. }\end{array}$} \\
\hline 39 & Newtown & Postmasburg/NC & \multicolumn{3}{|c|}{ Not yet open after burglary last year. } \\
\hline 40 & Ogobandlovu & Empangeni/KZN & \multicolumn{3}{|l|}{ Number does not exist. } \\
\hline 41 & Pafuri Thohoyandou & Thohoyandou/Limpopo & \multicolumn{3}{|c|}{ Number always engaged. } \\
\hline 42 & Pescodia & Kimberley/NC & Fax, PP, WP, Cp, IN & Cp, PP, Fax & 200 \\
\hline 43 & Petsane & Reitz/FS & $C T$, fax, PP, Cp, WP & Cp, Fax. WP & 20 \\
\hline 44 & Rocklands & Bloemfontein/FS & \multicolumn{3}{|l|}{ No answer. } \\
\hline 45 & Sanco Thaba Nchu & Bloemfontein/FS & \multicolumn{3}{|l|}{ No answer. } \\
\hline \multirow{2}{*}{46} & \multirow{2}{*}{ Siyabonga } & \multirow{2}{*}{ Orange Farm/Gauteng } & WP, CT & WP & 25 \\
\hline & & & \multicolumn{3}{|c|}{ Telkom services terminated due to high costs. } \\
\hline 47 & Siyakhana & Alice/EC & \multicolumn{3}{|c|}{$\begin{array}{l}\text { Telecentre not in use due to a burglary in Dec. } 200 \mathrm{I} \text {. No } \\
\text { response from USA. }\end{array}$} \\
\hline 48 & St John's Church & Ermelo/Mpumalanga & \multicolumn{3}{|l|}{ No answer } \\
\hline \multirow[t]{2}{*}{49} & \multirow[t]{2}{*}{ Sterkspruit } & \multirow[t]{2}{*}{ Sterkspruit/EC } & WP, CT, & & \\
\hline & & & \multicolumn{3}{|l|}{ No telephone lines yet. } \\
\hline 50 & Tembisa & Tembisa/Gauteng & $\begin{array}{l}\text { CT, WP, IN, phone } \\
\text { cards, secretarial } \\
\text { work for SMMEs }\end{array}$ & WP & 800 \\
\hline 51 & Tombo & Port St Johns/EC & \multicolumn{3}{|l|}{ No answer. } \\
\hline \multirow[t]{2}{*}{52} & \multirow[t]{2}{*}{ Tshatshu } & \multirow[t]{2}{*}{ Lady Frere } & Fax, Cp, PP & Cp & 50 \\
\hline & & & \multicolumn{3}{|c|}{ Telephone lines not working. } \\
\hline 53 & Tswelopele/Intuthuko & Vanderbijlpark/Gauteng & \multicolumn{3}{|l|}{ No answer } \\
\hline 54 & Village Software Institute & East London/EC & $\begin{array}{l}\text { CT, PP, fax, scanner, } \\
\text { WP }\end{array}$ & Cp, WP & $10+$ \\
\hline 55 & Zastron & Zastron/FS & \multicolumn{3}{|l|}{ No answer. } \\
\hline 56 & Zweletemba & Worcester/WC & \multicolumn{3}{|c|}{ Number engaged: out of order? } \\
\hline
\end{tabular}

Legend: Services: Cp (copying), CT (computer training), IN (Internet), PP (public phones), PSC (printer, scanner, copier), WP (word processing), Tel. (for office use only) ${ }^{\mathrm{a}}$

a. This inventory of services is based on the telephone interviews and does not pretend to supply a verified service audit.

The intention to provide access to telecommunications and information is clearly thwarted by problems with telephone lines. Eight interviewees referred to problems they experience in maintaining and offering telecommunications services to their clients. Telkom's inability to provide and maintain the lines was mentioned as well as the high costs of telecommunications. Most of these interviewees claimed that they would have had many more clients and therefore be much more sustainable if problems with regard to the telecommunications infrastructure did not exist.

The services most often used are word processing (64\%), followed by photocopying (48\%), and public phones (46\%). Only two interviewees mentioned that one of the preferred services is the Internet which is then mainly used by students. It has, however, not been established, but is assumed that the Internet is used for information seeking.

Clients visiting the telecentres who took part in the survey vary from between 4 to 800 per day with an average of 140 per telecentre per day. Four respondents mentioned that the numbers drop markedly during school holidays and that it is mostly students and school children who make use of the facilities. This information indicates that telecentres make some contribution towards education. Except for one interviewee who mentioned that clients visit the telecentre to obtain 'advice', little other evidence exists to indicate that telecentres are seen as information resources.

This inference is supported by the responses regarding the information needs of the clients. Most of the information needs mentioned are service-related and most of these queries are frustrations caused by the unreliable telecommunications infrastructure. The rest of the information needs identified agree in general with findings from other information needs analyses conducted in rural communities of South Africa (Maepa 2000). Strangely enough, no medical information needs were mentioned. Other information needs mentioned were employment-related information needs such as queries about study and employment opportunities as well as career guidance. Specific questions pertaining to government information were queries about social welfare (payments for pensioners and the elderly) and presidential speeches. Only four interviewees looked for other information, namely legal information (2) and community information (2). 
The first requirement for universal access is an available and reliable telecommunications infrastructure. No improvement in universal access, be it by means of a telecentre or not, is possible without a basic telecommunications infrastructure. The lack of a reliable and affordable telecommunications infrastructure is clearly the reason why many of these centres cannot fulfil the most basic objectives for which they were created. Neither is much information, especially of the type identified by government spokespersons and committees, being disseminated at these centres.

If the list obtained from the USA is reliable, the number of telecentres has decreased from 65 to 56 in two years (Benjamin et al. 200I). (This excludes the findings presented in this paper). Not much has materialised of the USA's resolve to 'embrace public access to telephony, computer literacy and Internet access in under-serviced areas as immediate objectives' (USA 2002). Khumalo's observations in his 1998 report (Khumalo, 1998) were proved true. Nothing has happened to change Schreiner's (Schreiner 1999) misgivings about technical problems and inadequate support from the USA.

\section{MPCCs}

The Government is currently driving MPPCs forward as the favoured initiative to attain the ideal of universal access to ICT and communication and eventually plans to have one MPCC per municipality across South Africa (Safrica 2002).

A Cabinet Memorandum of 1999 (South Africa. Cabinet Memorandum 1999) states that the GCIS hopes to establish 60 MPCCs using the National Inter-Sectoral Steering Committee (NISSC) as vehicle. The task of the NISSC which consists of representatives of government departments, parastatals, non-governmental organisations, research agencies and tertiary institutions, the private sector and other stakeholders is to ensure sustainability of the MPCC concept, quality service delivery and to play a role in the implementation and performance monitoring of MPCCs.

The report of the IDRC (Espitia, 200I) estimated the amount of fully functioning MPCCs at 47, of which 10 then formed part of the GCIS mandate. On the website of the GCIS (last updated on I2 November 200I) I4 MPCC sites are listed and a profile of most - including photos, contact details and a short description of location and services - is provided.

On 3I May 2002 a document, 'Template to be used by Managers of Provincial GCIS Offices to reflect the contact details of their MPCCs', was received on request from officials of the GCIS. Here 20 MPCCs are listed. This constitutes, in contrast to the USA telecentres, a growth.

These 20 MPCCs are listed in Table 2. The list indicates the status of management at the different MPCCs as well as contact possibilities.

Table 2 List of MPCCs as in May 2002

\begin{tabular}{|c|c|c|c|c|c|c|}
\hline MPCCs & Managers & Tel & Fax & Cell & E-mail & Postal address \\
\hline \multicolumn{7}{|l|}{ KZN } \\
\hline Mbazwana (Richardsbay) & Centre and $\mathrm{GIC}$ manager & $\checkmark$ & $\checkmark$ & $\checkmark$ & $x$ & $\checkmark$ \\
\hline Eastern Cape & & & & & & $\checkmark$ \\
\hline Tombo (Port St Johns) & GIC manager & $\checkmark$ & $\checkmark$ & $\checkmark$ & $x$ & $\checkmark$ \\
\hline Sterkspruit (Lady Grey) & Centre and $\mathrm{GIC}$ manager & $\checkmark$ & $\checkmark$ & $\checkmark$ & $x$ & $\checkmark$ \\
\hline Cofimvaba (Queenstown) & GIC manager & $\checkmark$ & $\checkmark$ & $\checkmark$ & $x$ & $x$ \\
\hline Limpopo & & & & & & $\checkmark$ \\
\hline Kgautswane (Ohrigstad) & Centre and $\mathrm{GIC}$ manager & $\checkmark$ & $x$ & $\checkmark$ & $x$ & $\checkmark$ \\
\hline Makhuva & $\mathrm{GIC}$ manager & $\checkmark$ & $\checkmark$ & $\checkmark$ & $x$ & $x$ \\
\hline \multicolumn{7}{|l|}{ Western Cape } \\
\hline Worcester & Centre and GIC manager & $\checkmark$ & $\checkmark$ & $\checkmark$ & $x$ & $\checkmark$ \\
\hline \multicolumn{7}{|l|}{ Mpumalanga } \\
\hline Matsamo (Schoemansdal) & $\mathrm{GIC}$ manager & $\checkmark$ & $x$ & $\checkmark$ & $x$ & $\checkmark$ \\
\hline Mpuluzi (Barberton) & $\mathrm{GIC}$ manager & $\checkmark$ & $x$ & $\checkmark$ & $x$ & $\checkmark$ \\
\hline \multicolumn{7}{|l|}{ Northern Cape } \\
\hline Galeshewe (Kimberley) & Centre and $\mathrm{GIC}$ manager & & & & & $\checkmark$ \\
\hline \multicolumn{7}{|l|}{ Gauteng } \\
\hline Vaal Sebokeng (Vereeniging) & Centre and GIC manager & $\checkmark$ & $\checkmark$ & $\checkmark$ & $x$ & $\checkmark$ \\
\hline Ratanda (Heidelberg) & GIC manager & $x$ & $x$ & $\checkmark$ & $x$ & $\checkmark$ \\
\hline Faranani (Tsakane) & Centre and GIC manager & $\checkmark$ & $\checkmark$ & $\checkmark$ & $x$ & $\checkmark$ \\
\hline Tembisa & Centre and $\mathrm{GIC}$ manager & $\checkmark$ & $\checkmark$ & $\checkmark$ & $x$ & $x$ \\
\hline
\end{tabular}




\begin{tabular}{|c|c|c|c|c|c|c|}
\hline Shoshanguve (Pretoria) & GIC manager & $\checkmark$ & $\checkmark$ & $x$ & $x$ & $x$ \\
\hline Zithobeni (Bronkhorstspruit) & GIC manager & $\checkmark$ & $x$ & $x$ & $x$ & $x$ \\
\hline \multicolumn{7}{|l|}{ Free State } \\
\hline Namahadi (Witsieshoek) & GIC manager & $\checkmark$ & $\checkmark$ & $\checkmark$ & $x$ & $\checkmark$ \\
\hline Botshabelo & Centre and GIC manager & $\checkmark$ & $x$ & $x$ & $x$ & $x$ \\
\hline Sediba (Thaba Nchu) & Centre and GIC manager & $\checkmark$ & $x$ & $x$ & $x$ & $x$ \\
\hline \multicolumn{7}{|l|}{ North West } \\
\hline Lebotlwane (Hammanskraal) & Centre and GIC manager & $\checkmark$ & $\checkmark$ & $\checkmark$ & $x$ & $\checkmark$ \\
\hline
\end{tabular}

Despite the fact that MPCCs are regarded as a priority service, this list in itself points to obvious problems (hopefully teething problems) with regard to management and telecommunications issues. Seven of the twenty MPCCs do not yet have a centre manager and one does not have a General Information Centre (GIC) manager'. If routes to contact the MPCCs are taken as an indication of the status of their telecommunication infrastructure, the picture again looks bleak. None of them have e-mail facilities, seven do not have a fax facility and five do not yet have postal addresses. A positive factor is, however, that all the MPCCs are located in disadvantaged, albeit not only rural, areas.

On 7, 10 and 13 June the telephone numbers (cell phones included) were phoned during office hours with the intention of conducting telephone interviews. The aim of the telephonic interviews was to establish to what extent the MPCCs provide telecommunications facilities and information to needy rural communities.

At the following MPCCs the telephone kept ringing on all three occasions and was never answered: Tombo, Vaal Sebokeng, Ratanda, Faranani, Zithobeni, Mpuluzi and Lebotlwane. The telephone numbers of the following MPCCs are not correct: Botshabelo, Sediba, Cofimvaba and Tembisa. They could therefore not be reached telephonically. That left ten MPCCs that were included in the telephonic interviews.

The questions asked and an analysis of the responses are presented in Table 3.

Table 3 Analysis of telephone interviews conducted with MPCCs

\begin{tabular}{|c|c|}
\hline Question & Analysis of responses \\
\hline What type of information is currently being provided? & $\begin{array}{l}\text { - Information of 'various government departments'. } \\
\text {-Information from the Departments of Labour, Home Affairs, Welfare, } \\
\text { Environment and Health, Minerals and Energy and Arts and Culture. } \\
\text {-Information from institutions such as the GCIS, Consumer Services, etc. }\end{array}$ \\
\hline $\begin{array}{l}\text { Which type of media is used to disseminate the } \\
\text { needed information at the MPCC? }\end{array}$ & $\begin{array}{l}\text { - Pamphlets }(7)^{\text {a }} \\
\text { - Oral(4) } \\
\text {-Community Radio(4) } \\
\text {-Video(2) } \\
\text {-Workshops(2) } \\
\text { - Posters, local newspapers, other publications and road shows and } \\
\text { exhibitions were mentioned only once. }\end{array}$ \\
\hline $\begin{array}{l}\text { Which telecommunication services are available at } \\
\text { the MPCCs in the form of telecentres? }\end{array}$ & $\begin{array}{l}\text {-2 have telecentres equipped with computers and telephone lines but no } \\
\text { telephones } \\
\text {-2 have a telecentre equipped with computers, telephones, a fax, a } \\
\text { photocopier and Internet access. } \\
\text { - I has a telecentre but is waiting for equipment promised by the USA. } \\
\text { - I has fax and telephone facilities, but no internet. } \\
\text {-3 have no telecentre and consequently no telecommunication services. }\end{array}$ \\
\hline How many people visit the MPCC per day? & Numbers vary between 30 to 600 . \\
\hline Which services are mostly used? & $\begin{array}{l}\text {-9 named the Department of Home Affairs } \\
\text {-5 mentioned the Department of Welfare } \\
\text { - I mentioned the Department of Labour }\end{array}$ \\
\hline
\end{tabular}

a. The number in brackets indicates the occurrence of the specific type of media at the MPCC

I. The centre manager is responsible for the day to day management of the centre, while the GIC manager liaises on behalf of the centre with the Government Communication and Information System (GCIS), other stakeholders and the community. 
Only two MPCCs house a telecentre which is fully equipped with telecommunications facilities including Internet access from which information on the government websites can be downloaded. The rest of the MPCCs depend on traditional media such as pamphlets and interpersonal communication for disseminating government information.

The MPCCs, although apparently more successful than the USA telecentres, nevertheless do not yet successfully provide access to telecommunications and information to disadvantage rural communities. The focus on the physical construction and establishment of these centres as seen in the widely publicised and launches of the centres (Seale 2002), distracts the attention from infrastructural problems indicated by the fact that more than $50 \%$ of the MPCCs could not be reached by phone.

According to these findings not much has realised in terms of the ideal that MPCCs should form the backbone of development communication and the dissemination of information to needy rural communities. It must be conceded that this initiative is still in a start-up phase. At this early stage, it does unfortunately seem as if problems with telecommunications infrastructure and management will also hamper this initiative.

It is safe to assume that MPCCs, like the USA telecentres, lack effective management, well-maintained and working equipment, relevant information as well as the much- advocated access to the Internet gateway that should empower the disadvantaged rural areas of South Africa.

Citizen's Post Offices (CPOs)

Currently, seven CPOs are in operation and the go-ahead has been given for 18 more to be erected by 31 March 2003 (Sivalingum 2002). The seven CPOs have been placed mainly in rural disadvantaged areas. Each one is equipped with what is referred to as an Internet café and 'business centre' with a minimum of seven and a maximum of thirteen Internet terminals per centre as well as facilities for copying, word processing, faxing, binding, scanning, laminating, etc. A Government Information Terminal (GIT), operating in the same way as a PiT, provides free online access to government information at all the centres (Sivalingum 2002). A trained administrator is appointed to operate the CPO and to assist clients. For any technical problems the administrators fall back on the facility staff of the South African Post Office (Mkhawanazi 2002).

A list of the existing CPOs with names and contact details was received from the South African Post Office. The same interview schedule used in the case of MPCCs and USA telecentres was used to conduct telephone interviews with the administrators of the CPOs. The findings of these interviews are presented in Table 4.

Table 4 Profile of CPOs as in August 2002

\begin{tabular}{|c|c|c|c|}
\hline CPO & Services mostly used & Clients per day & What type of info. do they ask for? \\
\hline Soshanguve & Copy & 85 & $\begin{array}{l}\text { Employment opportunities, websites and } \\
\text { government information. }\end{array}$ \\
\hline Elim & Copy & 7 & Information available on the internet. \\
\hline Thabanchu & Internet searches, copy, fax, e-mail & $80-90$ & How to use the internet and send e-mail. \\
\hline Flagstaff & Internet & $20-23$ & How to use the internet and send e-mai.l \\
\hline King William's Town & Fax, copy & 200 & Government services, how to use the PiT. \\
\hline Ngoma & $\begin{array}{l}\text { Internet searches, e-mail, fax, word } \\
\text { processing, copy }\end{array}$ & $100-150$ & How to use the computer. \\
\hline George & e-mail, internet searches, copy & 20 & Job opportunities. \\
\hline
\end{tabular}

The CPOs, in comparison with the other two initiatives, seem to be better managed, equipped and monitored. All have Internet access, and at least two CPOs surfing on the web and e-mail access are some of the 'most used services'. The type of information needs expressed by the users also indicate that information dissemination is taking place.

The CPOs have accumulated 2446 clients since inception (Mkhwanazi 2002) and this concept does indeed seem promising, but the reality is that in total only approximately 700 people currently use this facility per day.

\section{Is the government's centre approach delivering?}

The findings of the study above indicate serious problems with the centre approach as the answer to universal access and the dissemination of information to disadvantaged rural areas. The initial rationale of government in embracing the centre approach was to provide information to disadvantaged communities by using ICT infrastructure. The reality of the situation as presented in this article is that existing centres established with government support in South Africa are struggling, ill-managed communications shops where hardly any information is currently being disseminated. 
According to the findings of this study an average total of more or less 5000 clients use any one of the three types of centres per day in all areas of South Africa. If this number is compared to the 17,8 million previously disadvantaged Blacks living in non-urban areas (Survey of the IT industry and related jobs and skills in South Africa, 1999:2I) the impact of these initiatives over a period of four years is negligible.

Elsewhere in the world concern about the use of telecentres as a solution to bridge the digital divide and generate or support social and economic development in disadvantaged rural areas is also raised. The assumption in many telecentre projects, that providing ICT equipment will automatically mean that useful information will be made available to those who need it, is increasingly being questioned.

Cameron (2002) responds to the consensus view that a successful telecentre must be a local initiative with a strong ground-up focus and input on local issues, developments and opportunities. His concern is that 'few if any small communities truly possess the expertise necessary to manage all of the facets of a telecentre project' (Cameron, 2002:I). Menou (200I) identifies a hierarchy of processes that a developing community must face, namely the struggle for improved living conditions, the activities conducted within the community towards the above goal, the control of the community over the said activities and the availability of ICT facilities that may serve all the above. He emphasises that the ICT aspect is only one amongst many other instruments that a community could use in its development endeavours.

Gurnstein (2002) questions the lack of a profound and thorough analysis of the telecentre movement. He mentions, for instance, that even in a developed country such as Canada no high-level analysis on the experiences or results of telecentres exist, even though approximately $\$ 500$ million has been spent on the Community Access Program. The current situation in Canada is that the Community Access Program is floundering. Individual sites are making do as best they can with little besides 'good news stories' and anecdotes to guide them in their struggles towards sustainability (Gurnstein 2002).

In Africa, Acacia, for instance, has funded pilot telecentre projects as part of a program aimed at 'advancing the access of disadvantaged communities in Africa to modern information and communications technologies and to apply them to their own development priorities' (Benjamin, 2000:3). Some useful lessons have been learnt, but none of the funded telecentre projects have managed to create a model that can be rolled out to have a major impact in Africa, or South Africa.

Except for research by Benjamin no deep analysis at government level has been done in South Africa. Apart from a few exceptional 'good news stories' like those about Gazaleka in Mamelodi (Dagron 200I) - the latter has since turned into a bad news story - there is little indication of the existence of sustainable telecentres in South Africa. It seems as if the initial enthusiasm for telecentres has been unfounded.

\section{Conclusion}

Telecentres are in theory locations where telecommunications technologies are made available for local communities to access information that will lead and contribute to local development and are in theory ideally suited to fulfil the government's objectives. The present practice questions the theory and the current state of affairs in this regard should convince the South African government to proceed with caution on this road. Many changes will have to take place before or if the centre approach will be able to execute the government's intent to improve the quality and availability of information.

The alleged reasons why the centre approach in South Africa is apparently not successful are many and varied and have been documented before (Conradie, 1998, Benjamin et al. 2002). We would like to suggest three underlying reasons that go beyond mere operational problems:

- The unsubstantiated hype that ICTs are the answer to all social questions.

- The focus on technology which diverts attention from the necessity to first build human and social capital.

- The South African government's top-down approach in addressing social problems in spite of lip-service to the opposite.

Measures to overcome these barriers might be partly addressed by an open and collaborative relationship between the academic Information Science community and the government. This might prevent repeating the mistakes already highlighted in research.

Collaborative new research ventures that draw on existing knowledge of local and international social sciences research might produce innovative practices to improve human and social capital in South Africa.

\section{References}

ANC (African National Congress). 1994. The Reconstruction and Development Programme: a policy framework. Johannesburg: ANC.

Benjamin, P. 1988. Multi-Purpose Community Centres in South Africa. Johannesburg: NITF. 
Benjamin, P. 2000. Telecentre 2000: literature review. Pretoria: DRA-Development and LINK Centre.

Benjamin, P. and Dahms, M. 1999. Socialise the modem of production - the role of telecentres in development: telecentre evaluation, a global perspective. Ottawa: IDRC.

Benjamin, P., Stavrou, A., Burton, P. \& McCarthy, C. 2000. Telecentre 2000: synthesis report. Johannesburg: DRA-Development and LINK Centre.

Berlyn, J. 1998. Multi-purpose community centres and the dissemination of government information. Meta-info Bulletin, $7(4): 20-27$.

Cameron, D, 2002. (donc@mudgeeab.com.au) Beyond the digital divide: enabling the community with information and communications technologies. E-mail to communityinformatics@vcn.bc.ca, Received March 5, 2002.

Cisler, S. 1998. Telecenters and libraries: new technologies and new partnerships: paper delivered at the IFLA Conference, Amsterdam, August. Retrieved July 12, 2000 from http://home.inreach.com/cisler/telecenter.htm

CommUnity web site. 2002. Retrieved August 25, 2002 from http://www.communitysa.org.za

Colle, R. \& Roman, R. 1999. Communication centers and developing nations. Retrieved August 10, 2000 from http:// www.devmedia.org/document/Banga.htm

ComTask. 1996. Communications 2000: a vision for government communication in South Africa: final report of the Task Group on Communications to Deputy President Thabo Mbeki. Retrieved March 10, 2000 from http//www.polity.org.za/govdocs/ commissions/comtask.html

Conradie, P.D. 1998. Using information and communication technologies (ICTs) for development at centres in rural communities: lessons learned. Communicare, 17(1):97-II7.

Dagron, A.G. 200I. Making waves: stories of participatory communication for social change. New York: Rockefeller Foundation.

Ernberg, J. 1998. Telecommunications for sustainable development. In: Richardson D. (ed) The first mile of connectivity. Rome: FAO.

Espitia, D. 200I. Telecentre case study in South Africa: report I (b). Process analysis and strategy evaluation. Johannesburg: IDRC.

Gurnstein, M. 2002 (mgurst@vcn.bc.ca) Analysis. E-mail to (communityinformatics@vcn.bc.ca). Received March 9, 2002.

Gaspar, M. 2002. Telecottage - the chance for small communties for development. Unpublished paper delivered at the FOTIM workshop at the University of Pretoria, 8 March.

ITU (International Telecommunications Union). 1998. World telecommunications development report. Geneva: ITU.

Khumalo, F. 1998. Preliminary evaluation of telecentre pilot projects. Retrieved July 12, 2000 from http://www.itu.int//TU-D/ univ_access/evaluation/usa.ht

Kiplang'at, J. 1999. An analysis of the opportunities for information technology in improving access, transfer and the use of agricultural information in the rural areas of Kenya. Library Management, 20(2):I I5- I 27.

Maepa, M.E. 2000. Information needs and information-seeking patterns of rural villagers living in the Northern Province. Unpublished $D$ Litt et Phil thesis. Johannesburg: RAU.

Malan, C. 2002. Telecentres for higher education. Unpublished project report for FOTIM.

Maphatane, M. 2000. Status report on Multi-Purpose Community Centres. Pretoria: GCIS.

Mbeki, T. 1995. South Africa and the information superhighway: speech delivered at the G7 Conference on the Information Society, Brussels, Belgium, 27 February, 1995. In: Mbeki, T. (ed). 1998. Africa: the time has come: selected speeches. Cape Town: Tafelberg \& Mafube.

Menou, M. 200I. (michel.menou@wanadoo.fr) Telecentre defined. E-mail to (communityinformatics@vcn.bc.ca). Received December 8, 2001 .

Mkhwanazi, M. 2002. (MkhwanM@sapo.co.za) CPO information, E-mail to (mesnyman@postino.up.ac.za), Received September 26, 2002.

Naidoo, J. 1997. The role and vision of government in the emerging information society. Speech delivered at the National Information Technology Forum Dinner. Retrieved August 10, 2000 from http://www.doc.gov.za/docs/sp//997/sp97080I.html

Naidoo, J. 1998. Speech delivered at the World Telecommunications Development conference, Valetta, Malta. [Online]. Retrieved August 10, 2000 from http://www.doc.gov.za/docs/sp/l998/sp980324.html

NITF (National Information Technology Forum). 1996. Multi-Purpose community centre research report. Retrieved August I0, 2000 from $h t t p: / / w w w 2 . s n . a p c . o r g / m p c c / s e a r c h . c f m$

NTCA (National Telephone Cooperative Association). 1998. Conference proceedings from the National Telecomms Cooperative Association Conference, 'First International Conference on Rural Telecommunications', November - December. Retrieved April I0, 2000 from http://www.ntca.org

Post Office. 2000 Post Office: your business partner. Brochure.

Pahad, E. 1998. Budget vote, 29 (SACS) and the launch of the Government Communication and Information System (GCIS). Retrieved September 8, 2000 from http://www.polity.org.za/govdocs/speeches/1998/sp05II.htm

Richardson, D. 1997. The Internet and rural development : an integrated approach. Retrieved September 28, 1999 from http:// rtr.worldweb.net?Textonly/Zimprl.htm.

Richardson, D. \& Paisley, L. (eds) I 998. The first mile of connectivity: advancing telecommunications for rural development through a participatory approach. Rome: FAO.

Safrica. 2002. Government Services. Retrieved September 12, 2002 from http://www.safrica.information/public_ser

Schreiner, H. 1999. Rural women, development and telecommunications: a pilot programme in South Africa. Gender and Development, 7(2): 64-70.

Schuler, D. 1996. New community networks, wired for change. New York: Addison-Wesley Publishing Company.

Sivalingum, C. 2002. Personal Communication, (September, 5 2002).

Snyman, M., Holmner, M., Claasen, R., Mokgalabone, R. and Van Deventer, P. 200I. South African telecottage profile. Unpublished research report for the NRF.

South Africa. 1996. Constitution of the Republic of South Africa. 1996. Act 108 of 1996. Cape Town: Constitutional Assembly. 
South Africa. 1996. Telecommunications Act, 1996 (Act no. 103, 1996). Pretoria: Government Printer.

South Africa. 1997. License issued to Telkom SA Limited to provide telecommunication services under section 36 of the Telecommunications Act, 1996. Government Gazette, 383(17984).

South Africa. Department of Communications. 1998. Info.com 2025: the dawn of a new information age for Africa. Brochure.

South Africa. Cabinet memorandum. 1999. 19 November.

South Africa. Government Communication and Information System (GCIS). 1999a. A framework for a memorandum on government information centres. GCIS report, May. Johannesburg: GCIS.

South Africa. Government Communication and Information System (GCIS).1999b. The GCIS and Development Communication. GCIS report, July. Johannesburg: GCIS.

South Africa. 2000. South Africa yearbook. Pretoria: GCIS.

South African Post Office Limited. 1999. Public Information Terminals: project overview, Enquiry number: RFP 012/99/PLR: 3.

Strydom, M. 1998. The role and functions of the new Government Communication and Information System (GCIS). Meta-info Bulletin, 7(4):8-14.

Survey of the IT industry and related jobs and skills in South Africa. 1999. Retrieved April, 102000 from http://www.saitis.co.za/ studies/jobs_skills/index.html

USA (Universal Services Agency). 2002. Background. Retrieved September 2I, 2002 from http:www.usa.org.za/background.html

Van Audenhove, L. 1999. South Africa's information society policy: an overview. In: Proceedings of a conference on: The moral and legal challenges of the Information Era: 172-188. Pretoria: Centre for Information Development and Centre for Occupational Ethics, University of Pretoria.

World Bank. 1998. World Bank report. Washington DC: World Bank.

Zongo, Gaston (1999). What is a telecentre? A review of best practice and models. Paper delivered at a conference Building the Information Community in Africa, February 1999. Unpublished. 